\title{
Authorship, Omnipotence, and Charlotte Brontë
}

In The Life of Charlotte Brontë, Elizabeth Gaskell qualified her earlier reaction to Brontë's juvenilia - 'they are the wildest $\&$ most incoherent things' ${ }^{\text {' }}$ - into a more specific discomfort with 'the character of her purely imaginative writing. ${ }^{2}$ She sets out the problem in terms of a generic division: "While her description of any real occurrence is [...] homely, graphic, and forcible, when she gives way to her powers of creation, her fancy and her language alike run riot, sometimes to the very borders of apparent delirium' (Life 69). Cutting a clean distinction not only between content which is 'real occurrence' and which is 'purely imaginative', but between the nature of writing as 'description' and as 'creation', what Gaskell isolates for praise is the realistic as both subject and mode of representation. The juvenilia, she argued, were exercises from which Brontë 'formed those habits of close observation, and patient analysis of cause and effect, which served so well in after-life as handmaids to her genius' (68), or in other words, those habits of empirical description exemplified by the Life itself:

To counterbalance this tendency in Charlotte [for the imaginative], was the strong common sense natural to her, and daily called into exercise by the requirements of her practical life [...] to brush rooms, to run errands, to help in the simpler forms of cooking, to be by turns play-fellow and monitress to her younger sisters and brother, to make and to mend, and to study economy under her careful aunt. Thus we see that, while her imagination received powerful impressions, her excellent understanding had full power to rectify them before her fancies became realities. (70-71)

Just as this passage itself embodies the attention to everyday details and practicalities it seeks to establish in the young Brontë's performance of household chores, a clear parallel is drawn between Brontë's commitment to 'practical life' and to her writing of 'real occurrence' - that is, to the 'homely, graphic, and forcible' representations of life at the Parsonage which Gaskell's biography therefore comes to double. Like a hall of 
mirrors, the mimetic loop between Brontë's life, Brontë's writing of her life, and Gaskell's writing of the Life reflects and reinforces an analogy between domestic and literary work, emphatically revealing the female author as attentive rather than creative, responsible rather than frivolous, at work and not at play - whether in the home or on the page.

Gaskell's anxiousness 'to rectify' such a domestic portrait of the female novelist is representative of a cultural anxiety, particularly in fiction by women, about the novel's vicarious or virtualising functions. Her implication, that establishing Brontë's legitimacy as an artist requires emphasising 'common sense' over 'imagination', is more explicitly articulated by George Eliot's I 856 polemic against 'the most trashy and rotten kind of feminine literature', contemptible for being 'less the result of labour than of busy idleness' and for lacking 'those moral qualities that contribute to literary excellence - patient diligence, a sense of the responsibility involved in publication, and an appreciation for the sacredness of the writer's art'. ${ }^{3}$ At stake in their common appeal to 'labour', 'responsibility', and 'patient diligence' is the professional and cultural recognition of novel-writing as real work, performing duties and necessitating effort, a claim which is vulnerable to dismissal not only because of the precarious place of women in the cultural marketplace, but also due to the form's paradoxical logic of fiction. If the novel aspires as literature to difficult standards of excellence and seriousness, closely observing human nature or social reality in the abstract, the novel also produces as fiction a reality of invented particulars, where the omnipotent word of a silly novelist can make any heroine 'an heiress, probably a peeress', 'perfectly well dressed and perfectly religious', with 'a superb contralto and a superb intellect'. ${ }^{4}$ Gaskell and Eliot's insistence on 'practical life', not only as the proper subject of novelwriting but also its nature as an activity, legitimises an ostensibly documentary form by obscuring its obvious, concomitant function: the free creation of fictional lives.

This chapter reinstates the figure of the capricious, irresponsible, and omnipotent author - the author 'run riot' - to the foundations of Brontë's novel-writing. As Gaskell was probably aware, her suggestion of a 'counterbalance' between the real and the imaginative is misleading, belying an alternative but equally formative practice at play in Brontë's childhood: autobiographical accounts of 'real occurrence' are vastly outnumbered in the juvenilia by narratives about the imaginary worlds over which the Brontës ruled as massive, omnipotent gods called the Chief Genii, modelled after the whimsical spirits from James Ridley's popular Arabian Nights pastiche, The Tales of the Genii. Brontë's 'genius', a word Gaskell 
uses to mean a talent for 'close observation' and 'patient analysis', evokes in the context of these worlds the very opposite: the power of the author to create and determine fictional realities, to magically interfere with narrative 'cause and effect', and even to kill or resurrect characters with unabashed favouritism. The radical ambivalence of 'genius' undermines the careful characterisation Gaskell constructs around the origins of Brontë's writing as a domestic, laborious, and attentive activity - a realism of handmaids, service, and chores - suggesting instead the inseparability between two models of authorship: the author who treats writing as the dutiful 'description of any real occurrence', and on the flip side, the author who writes to exercise (or abuse) their 'powers of creation' (Life 69).

Understanding this other side of genius as an integral part of Brontë's literary training and practice, no less essential to her authorship than truthful representation or diligent empiricism, enables us to recover an underexamined (because disavowed) side to the realist tradition. The Genii mode of authorship does not disappear from Brontë's writing as an adult, but inheres in a vicarious quality to her novels which has been recognised both as a major condition of their appeal and as aesthetically embarrassing. For one thing, I think an author who writes fiction as a power fantasy or vicarious game is probably a more 'realistic' picture of a thirteen-year-old than that of a canonical artist in training. For another, defensive characterisations of the novel like Q. D. Leavis's (of Jane Eyre) as a 'fable of wishfulfilment $[. .$.$] a favourite form of self-indulgence' also suggest the inex-$ tricability of the child at play from the novelist at work. ${ }^{5}$ That this kind of novel-writing can only be acknowledged as disparagement reveals Leavis's inheritance of a critical attitude towards 'Silly Novels by Lady Novelists'; but what if we approached vicariousness and self-indulgence not as charges from which Brontë requires rescuing, but as motives essential to her practice and experience of fiction? Rather than holding the novelist to their apparent responsibilities to depict and engage in 'practical life', I argue that such uses of writing as biographical escapism or 'wish-fulfilment' are intrinsic to the tradition and value of realist fiction, even while they are repudiated as immature or inartistic.

\section{'A Divine Game'}

'[W] must always bear in mind', Vladimir Nabokov lectured in the I950s, 'that art is a divine game. These two elements - the elements of the divine and that of the game - are equally important. It is divine because this is the element in which man comes nearest to God through 
becoming a true creator in his own right. And it is a game, because it remains art only as long as we are allowed to remember that, after all, it is all make-believe'. ${ }^{6}$ For Nabokov as (more recently) for Lowe, literature's persuasiveness has been overrated as a factor of its function and power, at the cost of proper attention to literature's artificiality. As Lowe argues, the concept of belief is a distracting non-starter for understanding how literature makes us imagine, a difference which is more than 'a mistake as to the degree of conviction involved. Imagining the heat of the sun on your back is about as different an activity as can be from believing that tomorrow it will be sunny'. ${ }^{7}$ As Nabokov suggests, to lose a distinction of fiction's imaginariness and how 'we are, as readers or as spectators, participating in an elaborate and enchanting game' is no longer to experience something as art, but as that 'which should belong in a newspaper instead'. ${ }^{8}$ Maintaining this double consciousness of an explicitly imaginary reality is partly a matter of cognitive attitude, something to 'always bear in mind', but also partly of literary form, of being 'allowed to remember' that it has all been made up. And if, as this book argues throughout, games of make-believe are an effective analogy for framing this essential logic of fiction, Nabokov's other 'equally important' analogy draws more specific attention to authorship as a mode of fictional action.

An analogy of the author as divine creator assumes by implication the nature of authorship as a form of action upon virtual worlds - most notably, the act of genesis. In his 1939 essay 'On Fairy-Stories', J. R. R. Tolkien famously described the storyteller as a "sub-creator" [...] mak[ing] a Secondary World which your mind can enter. Inside it, what he relates is "true": it accords with the laws of that world'. ' This model of mythological or more generally literary production, he argues, involving 'sub-creation, rather than either representation or symbolic interpretation [...] is, I think, too little considered'. ${ }^{\text {Io }}$ Similarly, M. H. Abrams's I953 study The Mirror and the Lamp proposed as its central thesis that eighteenth-century poetic theory underwent 'the replacement of the metaphor of the poem as imitation, as "mirror of nature", by that of a poem as heterocosm, a "second nature", created by the poet in an act analogous to God's creation of the World'. ${ }^{\text {I }}$ Abrams in turn cites Elder Olsen's more radical argument in 1942 that, to the material world depicted by the narrative, the author's word constitutes miracle:

[E]very poem is a microcosmos, a discrete and independent universe with its laws provided by the poet; his decision is absolute; he can make things good or bad, great or small, powerful or weak, just as he wills; he may make men taller than mountains or smaller than atoms [...] he may destroy 
creation or re-form it; within his universe the impossible becomes the possible, the necessary the contingent - if he but says they do. ${ }^{12}$

In such formulations, figuring the author as god is really to make two analogies, inseparable from figuring fiction as a world upon which divinity acts, first by its creation and then - more problematically - with omnipotent control. If the rhetorical stakes of this analogy are sometimes construed as an argument for freedom of expression, particularly regarding the choice of fantastical subjects in literature, its greater implications concern this sense or pretence in which authors do something to fictional objects by making narrative decisions about them.

As we have seen, however, playing god can be an uncomfortable analogy for the professional activity of authorship; the divine poet has their counterpart in the silly novelist. However valorised as a metaphor of literature's power to create, the practice of fiction by say-so represents exactly the kind of irresponsible authorship Eliot saw as rendering all heroines immoderately fortunate and beautiful. In his footnote to Olsen, Abrams therefore appends a 'warning against the advisability of utter freedom, in the fashion of miracle', implying that what a poet can do in a fictional world may not be what they should do in a literary work. ${ }^{13}$ This conflict between fiction and literature - between the omnipotent freedom of the author and their empirical, moral, or social duties - is especially intensified for the novel, committed at the same time to fiction's noncorrespondence with actuality and to a referential plausibility that might well 'belong in a newspaper. ${ }^{\mathrm{I}}$ More so than the poem or the fairy-tale, the novel must negotiate between these inseparable antitheses of its form; as Gallagher argues, 'If a genre can be thought of as having an attitude, the novel has seemed ambivalent towards its fictionality - at once [...] coax[ing] readers to accept the imaginative status of their characters [...] and conceal[ing] fictionality by locking it inside the confines of the credible'. ${ }^{\text {Is }}$ An omnipotence over the credible makes the novel in particular more ethically troubling than Nabokov's experience of 'art' in general, because the novelist exercises their imagined power over a world that resembles our own (rather than of unicorns or elves), over recognisable causes and effects which are not ordinarily so compliant to human will. The novel's attempt to be simultaneously reality-shaping and real-seeming is a powerful component of its appeal, but also an inherently unstable combination of values and functions.

Charlotte Brontë's career affords a uniquely literal case of this negotiation between 'a divine game' and the realist novel, embodied by her uneasy 
personal transition between childhood play and literary work. In correspondence with William Smith Williams, the literary adviser for Smith, Elder \& Co., Brontë the professional novelist conceived 'The first duty of an Author' to be 'a faithful allegiance to Truth and Nature [...] a conscientious study of Art as shall enable him to interpret eloquently and effectively the oracles delivered by those two great deities' ${ }^{16}$ To these household gods, Thackeray's social satires particularly ordained him in her opinion as 'the legitimate High Priest of Truth'; the second edition of Jane Eyre is dedicated to the author of Vanity Fair. But if Brontë's views in I 848 presage her own posthumous portrayal by Gaskell and Eliot, representing authorship as an empirical duty performed with hard-honed skill, the overwrought language of their expression evokes neither naturalistic observation nor Christian revelation, but a more fantastical process of divining truth from art. Like Gaskell, too, Brontë's praise of another's realism finds an ambivalent foundation in the developing novelist, in what she further identifies as Thackeray's 'inherent genius: the thing that made him - I doubt not different as a child from other children [...] that now makes him a writer, unlike other writers' ${ }^{17}$ These two characterisations observant oracle and creative genius - again suggest not one cohesive ideal of the novelist but a set of contradictory positions, the receiving of 'delivered' truth and its production from within, drawn together by an origin myth that clearly recalls Brontë's own unique making as a child writer.

\section{Youthful High Spirits}

The Brontë of the juvenilia is not so much interested in attendance upon other, abstract deities as in what Gaskell would call her own 'powers of creation' (Life 69). In the second earliest extant manuscript by any of the Brontë siblings (the earliest is a fragmentary narrative from I 826-28), a document dated March I 2 th, I 829 and entitled 'The History of the Year', Brontë presents another, very different oracular account of authorship. Even as a text that inaugurates a textual history of the Brontës, as its title implies, the 'History' is itself already preoccupied with examining a moment of origination. Looking back over the 'three great plays' of make-believe that Brontë and her siblings (Branwell, eleven; Emily, ten; Anne, nine) had formed since I 826 , the document attempts to 'sketch out the origin of our plays more explicitly if I can':

Young Men, June I 826 [...] Branwell came to our door with a box of soldiers. Emily and I jumped out of bed and I snatched one up and 
exclaimed, 'This is the Duke of Wellington! It shall be mine!' When I said this, Emily likewise took one and said it should be hers [...] Emily's was a grave-looking fellow. We called him 'Gravey'. Anne's was a queer little thing, very much like herself. He was called 'Waiting Boy'. Branwell chose 'Bonaparte'.

Our Fellows [later referred to as The O'Deans], July I 827 [...] The origin of the O'Deans was as follows: we pretended we had each a large island inhabited by people six miles high. The people we took out of Aesop's Fables. Hay Man was my chief man, Boaster Branwell's, Hunter Anne's and Clown Emily's. Our chief men were ten miles high except Emily's who was only four.

Islanders, December I 827 [...] The origin of the Islanders was as follows. It was one wet night in December, we were all sitting round the fire and had been silent some time, and at last I said, 'Suppose we had each an Island of our own'. Branwell chose the Isle of Man, Emily Isle of Arran and Bute Isle, Anne, Jersey, and I chose the Isle of Wight. We then chose who should live in our Islands. The chief of Branwell's were John Bull, Astley Cooper, Leigh Hunt, etc.; Emily's Walter Scott [. . . etc.; Anne's Michael Sadler [. . .] etc.; and I chose Duke of Wellington and son, North and Co.; 30 officers, $\mathrm{Mr}$ Abernethy, etc. ${ }^{\text {I8 }}$

Taken together, these accounts represent the 'History' of a developing process of worldplay; more fundamentally, they also capture the Brontës' initial assumption of a distinctive fictional mode. For one, these accounts emphasise possessiveness, reflective of children who clearly want to own things ('It shall be mine!'), but also of a developing power to handle fictional objects. The siblings graduate in the types of things they claim: bodily acts of seizure in I 826 , as Brontë 'jumped out' and 'snatched [...] up' the toy she claims as the Duke of Wellington, are followed by more abstract but explicitly analogous acts of selection - 'Emily likewise took' and 'Branwell chose' their respective wooden figures - which also later describe indisputably non-material acts of how 'we took out of Aesop's Fables' and 'I chose the Isle of Wight'. If the siblings' games become greedier over time, growing from a single wooden soldier apiece to ' 30 officers' and a private island, the common pool represented by Branwell's toy box also expands to transform everything the siblings encounter in their reading - literary works, national newspapers, world history and geography - into potential resources of play, options from which to take and choose.

The Brontës move from an autobiographical world of material toys towards a fictional world of referential objects. Not only do they begin to use the names of persons and places as possessions to be shared, the siblings were also obviously aware that these references had real-world 
(or intertextual) referents about which or whom they were not writing truthfully, deceitfully, or ironically. By making fictional copies to play, they intuitively grasp the language game of reference without correspondence; if one of the most visible innovations of the early novel is the invocation of proper names that strongly appeared - but explicitly did not - refer to real individuals, the Brontë juvenilia magnify this paradox by severing any correspondence between even the proper name of an embodied individual from any referential claim about that person. Arthur Wellesley, the Duke of Wellington - who in the world of the 'plays' colonises Africa, swallows poison, fights kidnappers, and dies twenty-three years before his historical death - becomes a detachable identity applied over the anonymous body of the wooden soldier, imbued with the real duke's resemblance but not his ontological status. As Firdous Azim has also argued, while 'resemblances between the fictional world of the Brontë juvenilia and its journalistic sources are easy to draw', this process of 'wholesale incorporation into the juvenilia (albeit in a fictionalised form) [...] shows the participation of the juvenilia in the fact/fiction dichotomies of the novelistic genre'. ${ }^{19}$ Only by these generically distinctive protocols of make-believe reference can one afford the temerity to specify 'the Isle of Wight' as a fantasised personal domain.

For another, these origins mark the beginning of an expanding set of possible fictional actions. If the Brontës learn over I826-27 a licence to borrow the images of actual objects for fiction, the siblings also come to understand their broader power as authors over imagined states of affairs, starting with the creation of such states and then with the making of choices about them. Games of make-believe, as Pavel has noted, require an understanding of actions in two perspectives:

Now when a group of children play with mud, they simultaneously touch globs of mud - in the really real world - and offer one another tasty pies in the world of make-believe [...] to account for our participation during such games, in both the really real world and the fictionally real worlds, we must distinguish between the two distinct levels on which the game takes places and show the links between them. ${ }^{20}$

Brontë's interest in going over old acts of play is motivated by exactly such an attempt to 'show the links' between perspectives, between acts of play in the Parsonage and their consequences in the imagined world. Inverting Gaskell's separation between 'real occurrence' and the 'purely imaginative' (Life 69), the 'History' repeatedly pinpoints moments where actions in 'the really real world' bring 'fictionally real worlds' into being: 'The origin of 
the Islanders', for example, is divided into a distinct (yet linked) before and after by a point over which autobiographical observations suddenly give way to much more unusual statements. Captured between the two radically different sentences of 'we were all sitting round the fire and had been silent some time' and of 'Branwell chose the Isle of Man' (EW 6) is the creation of a second perspective to whose objects the latter refers; textually caught between them is the sentence which 'at last' breaks both the silence of the room and the strict factuality of the account, 'Suppose we had each an Island of our own' (6). Brontë's imperative calls in the moment on her siblings, and afterwards on readers of the 'History', to assume the structures of pretence that allow the otherwise incoherent statements that follow - 'I chose Duke of Wellington and son' (6) - to function meaningfully and effectively as decisions (or for the 'History', as an account of decisions). 'Suppose' makes available something to be decided about in the first place, creating the world, reality, or paracosm in which fictional actions become available to be literally performed.

Authorship of the juvenilia consists both in the literary production of texts, an act to which the Brontës aspired with great seriousness by handwriting and -binding their manuscripts, and in the production of fictional consequences, the more extravagant actions of another world which uses 'writing itself as a vehicle of magical power'. ${ }^{2 \mathrm{I}}$ This double perspective persisted beyond Brontë's initial fascination with how her language had brought realities into paracosmic existence, and she continued experimentally to flex this power with another composition four months later. A letter written from the perspective of a 'Young Men' character, this is the one example of Brontë's 'wild weird writing' Gaskell chose to excerpt into the Life, and with which she evidently struggled, hazarding that it 'may have had some allegorical or political reference, invisible to our eyes, but very clear to the bright little minds for whom it was intended' (Life 70). Rather than a clever satire, however, the letter depicts 'the bright little minds' themselves in the guises of the Chief Genii - named Tallii, Brannii, Emii, and Annii - creators of the narrator's world who also periodically threaten its destruction:

It is well known that the Genii have declared [...] that by their magic might they can reduce the world to a desert, the purest Waters to streams of livid poison, and the clearest lakes to stagnant waters, the pestilential vapours of which shall slay all living creatures except the blood-thirsty beast of the forest, and the ravenous bird of the rock. But that in the midst of this desolation the palace of the Chief Genii shall rise sparkling in the wilderness $[\ldots]$ they shall have their annual feast over the bones of the dead, and shall 
yearly rejoice with the joy of victors. I think, sir, that the horrible wickedness of this needs no remark and therefore I haste to subscribe myself, etc. $(E W 39)$

The omnipotence of the Chief Genii strikingly anticipate what Olson would theorise as the right of the divine poet 'to make things good or bad, great or small [...] destroy creation or re-form it', expressed in similarly hyperbolic and hypothetical oppositions from 'the world to a desert', from 'purest Waters' to 'livid poison', from 'all living creatures' to only 'the ravenous bird'. ${ }^{22}$ The letter's playful adoption of a view from the ground suggests how such a theory of artistic licence might appear to those unfortunate enough to live in the 'microcosmos' of the literary work, for whom the potential arbitrariness of authorial whims is not only (as for Eliot) aesthetically silly but actively dangerous, revealing the narrative or ontological precarity of their existence as imagined beings. ${ }^{23}$

The Chief Genii are metafictional self-portraits of the juvenilia's authors which reflect an exultation in the freedom of fictional possibility or action, and simultaneously, their consciousness of how such freedom might infringe upon an implicit code of behaviour. As the character in the letter protests, comically moralising their own author, 'the horrible wickedness' of writing a destructive, meaningless apocalypse 'needs no remark' ( $E W$ 39); a position which critics of the juvenilia have tended too readily to echo. Laura Forsberg, who likewise reads the Genii letter as exploring 'the consequences of imaginative authorship', chooses to emphasise Brontë's transition away from 'childhood fantasies of supreme power' to becoming more 'involved in imagining her characters' experience of powerlessness [...] how her arbitrary power over the world of Glass Town impacts its citizens'. ${ }^{24}$ An implicit privileging of the latter position, of arbitrariness as a narrative problem rather than as authorial prerogative, similarly underpins Heather Glen's argument that, while the Chief Genii 'bespeak the child's heady assertion [...] of a coveted fictional power', the perspective of the juvenilia inheres 'not, most prominently, [in] identification with power, but, far more centrally and intimately, the imagining of powerlessness [...] a sense of self not as autonomous and free, but as dependent and determined, not as omnipotent, but as potentially not existing at all'. ${ }^{25}$ This critical inclination to disidentify Brontë from the juvenilia's acknowledged fantasies of power, and conversely to reframe them as really imagining perspectives of 'powerlessness' - even though what the characters are powerless against is the figure of the author herself - is for one, not an interpretation necessarily demanded by the archive's other narratives, and 
for another, revealing of a discomfort with what it means for an author to act for themselves.

In the Genii letter, locating authorial sympathy and an ethical burden in the narrator's bathetic reprimands - 'horrible wickedness' - overlooks the clear relish with which the text describes the potential gratuitousness of authorial action. As Dickens writes of Punch, acting fictionally may be all the more secretly satisfying for being wicked, 'an outrageous joke' of harmless violence exempted from the need to be 'moral and instructive [...] or a model for any kind of conduct', allowable only in vicarious form within one's proprietary universe. ${ }^{26}$ Even as they recognise Brontë's growing understanding of writing as a form of fictional action, Glen's and Forsberg's readings undervalue action's own satisfactions, advancing towards interpretations whereby authorship is only a means of constructing more traditional types of literary meaning. The argument that the Chief Genii only function to set up scenarios for Brontë to reflect on the experience of helplessness - as opposed to living out the indulgent experience of making her creations helpless, the exercise of authorship as an experience in itself - continues to assume a familiar model of the author which it is the juvenilia's potential to defamiliarise. We know well the literary functions and values of representing people in trouble, of reflecting on the limited agency that characterises our universal relation as historical individuals to the world. Forsberg's approach to interpretation is explicitly shaped by such an understanding of literature, connecting the juvenilia to the novel and its assumed work in expressing the urgent conditions (as Gaskell put it) of 'practical life':

Rejecting a child's fantasy of authorship, Charlotte Brontë instead finds an opportunity, within the epic tales of empire, to explore the feelings of mental and physical constriction which would later occupy the pages of her full-length novels. Within the miniature world of Glass Town, Charlotte Brontë discovered not an escape from the realities of Haworth, but rather a reflection of her own feelings of smallness and vulnerability in the carefully constructed psychologies of her characters. ${ }^{27}$

But how else can we use literature than as a remodelling of the constricting relations of real experience, especially - as the Chief Genii demonstrate with their 'magic might' - when fiction affords different kinds of relation to less intransigent realities? What can one experience vicariously in a 'miniature world' they specifically cannot in 'the realities of Haworth'? Moreover, the juvenilia's place at the foundations of Brontë's writing might perform Forsberg's argument in reverse, or in backlash: might not 
the grown-up fictions of the novel, too, be reprimandable for irresponsible uses of power?

\section{The Genie in the Novel}

These are fundamental questions which the juvenilia not only raise as implicative examples but are themselves interested in testing. They are natural questions for an adolescent author to ask: what is fiction for, and how can it create satisfaction? Besides the joy of being able to perform it (reason enough in itself), much of the arbitrary magic in the juvenilia also serves repeatedly to bring such problems to the surface of narrative. In a tale from June I 829 , set in the 'Islanders' play, the siblings again assume supernatural forms as the fairy-like 'Little King and Queens', roughly equivalent figures to their Genii identities in the 'Young Men' play. The Queens themselves narrate this story, where a character's attempt to poison the Duke of Wellington is both obstructed by the narrative and assisted by the author:

[Ned] reached the park gate. But here, a great obstacle presented itself, for the keeper of the gate is an old veteran, who has followed the Duke through all his wars, and attended him in all his battles [...] Ned turned round and seeing us, he said, 'Little Queens, will you open that gate?'

As we wished to see the end of this adventure, we took Raton up and threw him over the high wall, and then knocked at the gate. $(E W 26)$

By personally helping Ned (also known as Raton) overcome the 'great obstacle' which she herself wrote into the story, Brontë again alternates between two perspectives of fiction: a description of the character's helplessness to what 'presented itself as fact, and a power to make fiction conform to what 'we wished'. This double vision also manifests in the different levels of 'seeing' at work in the passage: Ned physically 'seeing' behind him in the material reality of the story, and the Little Queens wanting to 'see the end of the adventure' (26).

To say what the author 'wants' with such tales is not to interpret a literary intention, nor even just to describe a participatory experience, but to acknowledge a will to make particular and desirable narrative outcomes occur. If the siblings are fairly impassive about Ned's aims as a character they will help him to see what happens - they are not impartial about his success. Ultimately, Ned's poison itself proves a short-lived 'obstacle', impatiently overcome when 'His Grace's features collapsed with agony, the volume fell from his hand, and he sank into his chair. Just then, a loud yell rang in our ears, a rushing noise was heard and a Giant of Clouds [...] 
touched the Duke and new life seemed to be given him' ( $\left.E W W_{28}\right)$. Although the narrative builds up to Ned's assassination, it takes less than a paragraph for the Duke to fall ill and recover - the application of divine intervention 'Just' as the narrative reaches its logical conclusion is characteristic of such resurrections in the early juvenilia. In another 'Young Men' tale from August I 830, entitled 'A Day at Parry's Palace', Brontë's character Charles Wellesley writes of travelling from his native Glass Town to the territory of Emily's characters. (In a pointed comparison between Brontë's tastes and her sister's, Charles finds the town cramped and ugly, with dull and badly dressed residents.) The tale reaches its climax when one of Anne's characters, invited for dinner, almost dies unglamorously of overeating:

All ate as if they had not seen a meal for three weeks [...] I expected some blow-up after the surfeit which Ross, if I might judge from his continued grunting and puffing, had evidently got, and was not disappointed. An hour subsequent to dinner, he was taken extremely sick. No doctor being at hand, death was momentarily expected and would certainly have ensued, had not the Genius Emily arrived at a most opportune period; and when the disorder reached its crisis, she cured with an incantation and vanished. ( $E W 232)$

Unlike the Duke's poisoning, this example of sudden reversal clearly indicates a conflict between the sisters; but this conflict is also premised on the perceived stakes of a desired fictional outcome which is independent of, in fact contradictory to, narrative coherence. Exactly as the 'Giant of Clouds' interrupts that earlier tale 'Just' (28) as it almost resolves, the Genius's arrival 'at a most opportune period [...] when the disorder reached its crisis' forestalls the twice-'expected' result of what had been developing for 'An hour' and 'would certainly have ensued', and had been carefully anticipated by descriptions of Ross 'grunting and puffing' (232). These moments of narrative short-circuiting - 'death was momentarily expected' - again employ and conflate two modes of authorship, the unreported 'incantation' with which Emily directly acts upon the fictional world, and the narration of objective description with which Brontë plots (both in the sense of narrative and of assassination) to kill off her sister's character. The narrative consequences for which the respective siblings 'wished' transparently motivates both modes of authorial action.

Such experiments with writing might elicit certain critical affects embarrassment, discomfort, humour, dismissiveness - because they appear jarring, immature, or unprofessional (of course, they are); or because their yet unsettled state recalls uncertainties we tend to smooth over in the 
canonical realist novel. For instance, if the irresponsible omnipotence of the Chief Genii contravenes Eliot's sense of 'the sacredness of the writer's art', Eliot begins Adam Bede with her own distinctly non-Christian analogy: 'With a single drop of ink for a mirror, the Egyptian sorcerer undertakes to reveal to any chance comer far-reaching visions of the past [...] With this drop of ink at the end of my pen, I will show you the roomy workshop of Mr. Jonathan Burge'. ${ }^{28}$ Frank Kermode has noted how this passage functions 'as a magical means of making present what is absent [...] a past period', but as Jane Moore has argued, the suggestion that realist representation paradoxically depends on 'magical means' constitutes a 'postmodern act of complicating and complexifying the presentation of meaning': ${ }^{29}$

Ironically, an analogy comparing the magic powers of the narrator to look back into the past [...] with the conjuring tricks of an Egyptian sorcerer, that has the declared aim of testifying to the transparency of language and its corresponding realist effect, simultaneously brings realism into the foreground as a theoretical problem. It is the artificial, made-up, and in consequence un-real, nature of the story about to be told that the analogy draws to attention. ${ }^{30}$

As Hillis Miller also argues, 'The metaphor of the mirroring drop of ink calls attention, in the opening sentences of the novel, to puzzling aspects of mimetic theories of language [...] performative writing that creates what it seemingly only describes'.$^{3 \mathrm{I}}$ Eliot's sorcerer complicates the realist project not only because magic powers are dishonest or unrealistic (they aren't if they work), but because to do things by magic is to reveal the make-believe omnipotence beneath the 'labour' or 'patient diligence' of novel-writing the production of reality by fiat.

What the child knows, but the novelist will not openly admit, is that it is no fun to be the god of a world only to be sidelined from the action; to engage in the pleasure of pretence, only to pretend to observe the struggles of others. From their 'origin', Brontë's juvenilia continually seek ways to acknowledge the author's intrinsic power over the fictional world because it is satisfying to do so - which is afforded only by explicitly recognising the artificiality of that world, its unique possibilities as a reality manufactured by the author. If the realist novel has traditionally been understood as disavowing such acknowledgement, these disavowals are self-conscious circumventions of the form's inherent fictional logic. Being an honest sorcerer, oracle, or genius, a novelist could make the narrative this or that, make it up as one pleases - but of course such powers must be used for good, and so what is being conjured is precisely 
what least requires conjuration, a faithful representation of life as it is. As George Levine has argued, 'the characteristic subject of realist fiction is [...] disenchantment. The single character is implicated in a world of the contingent and must make peace with society and nature or be destroyed'. ${ }^{32}$ This is the perspective of the traditional bildungsroman, and of the Genii letter's narrator, confronting a world which is determined by forces beyond himself. At the same time, such narratives of contingency are 'dramatized in an entirely imagined world [...] that belies the determinist conception of the powerlessness of the imagination'. ${ }^{33}$ The juvenilia's unembarrassed pleasure in this latter perspective, the joy of having power to make and wreck, can help to make visible the other side of the novel's ambivalent attitude: a will to exercise the rights inherent to the novelist as divine creator.

\section{'Another Realism'}

At the heart of the jarring or comical unrealism of the Brontë juvenilia is not its adoption of the 'purely imaginative' over 'real occurrence' (Life 69) - that is, not the violent, hyperbolic, and fantastical contents of play but its conception of reading and writing as a form of action between two separate realities. Its most disconcerting moments share a common denominator in the physical presence of the author and her siblings in the world of the narrative. What is for children a natural inclination to participate in their own game is, for narrative theory, what Gerard Genette defines as 'metalepsis', the 'intrusion by the extradiegetic narrator or narratee into the diegetic universe'. ${ }^{34}$ In principle, Genette notes, narration represents the only permissible type of 'transition from one narrative level to another', the world of the book speaking to the world of the reader, besides which 'Any other form of transit is, if not always impossible, at any rate always transgressive [...] [and] produces an effect of strangeness that is either comical [...] or fantastic'. ${ }^{35}$

Moments like Emily's intrusion into 'A Day at Parry's Palace' suggest, for one, the indifference of the juvenilia to conventional principles, and for another, a contextual account of their conventionality. Most nineteenthcentury British readers had (at least notionally) a stronger philosophy than narrative theory of how authors interacted with their creations: as Gustave Flaubert advised in I 852, 'An author in his work must be like God in the universe, present everywhere and visible nowhere [...] Art being a second nature, the creator of that nature must operate with analogous procedures: let there be felt in every atom, every aspect, a hidden, infinite 
impassivity'. ${ }^{36}$ As Dorothy Sayers writes in her 194I book The Mind of the Maker, realism's version of the divine game is played on New Testament rules:

Whatever we may think of the possibilities of direct divine intervention in the affairs of the universe, it is quite evident that the writer can - and often does - intervene at any moment in the development of his own story: he is absolute master, able to perform any miracle he likes [...] he can twist either character or plot from the course of its nature by an exertion of arbitrary power [...] in fact, behave exactly as, in our more egotistical and unenlightened petitions, we try to persuade God to behave. ${ }^{37}$

As 'egotistical and unenlightened' as they are (as even their own characters accuse them to be), the transgressions of the Chief Genii are theological as well as narratological, disconcerting the 'analogous procedures' of a godlike author modelled on the Christian God. If artistic creation is for Nabokov 'the element in which man comes nearest to God', this is a privilege which Sayers perceives as involving significant responsibilities, transforming moral questions of divine action into aesthetic ones. ${ }^{38}$

What writing the real means for realism is a fundamental assumption about how meaning, the coherence imposed by a transcendent force, is incarnated into reality; and it is this assumed relation that the Brontë juvenilia disrupts. As Jacques Rancière has argued, the philosophical backdrop to the realist novel is 'the Christian separation between individual subjectivity and an absolute that has deserted the world with the body of the resurrected Christ [...] Novelistic 'modernity' inherits as content the Christian distance between the individual and his god'. ${ }^{39} \mathrm{His}$ argument follows Erich Auerbach's formulation of realism as 'transcendence materialized in ordinary life':

[T] he novel, as modern - realist - genre of literature is possible beginning at the moment when the 'totality of life' is no longer given in merely the extensive dimension of actions situated on one single level, but in which the intelligibility of gestures, words, and events recounted passes by a vertical relation to a background that arranges them in dramatic perspective and as a destination of humanity. ${ }^{40}$

If a 'vertical relation' between two separated but tenuously linked levels recalls Pavel's model of play, it is however one that insists on the abstraction of one level into the particularities of the other. It is this kind of authorship, dispersed into the fabric of the text, which Roland Barthes has in mind when he declares the deconstructive 'Death of the Author' as 'an activity we may call countertheological [...] for to refuse to halt meaning is 
finally to refuse God and his hypostases, reason, science, the law'. ${ }^{4}$ Making little distinction between the author and 'the "message" of the Author-God', Barthes's claim to have 'buried the Author' in fact inters something oddly bodiless, a will and a presence dissolved into fiction as 'message', 'meaning', and 'hypostases'. ${ }^{42}$

While it is evidently possible to interpret the juvenilia's fictions along this model, as narratives in which authorial intentions express themselves through the represented circumstances of life, this is a necessarily partial tactic for locating the author in a world where the Chief Genii exist. It is likewise must more difficult for Barthes to excise from the text the authorial presences of the Little King and Queens, who are not reflecting, sympathising, or moralising invisibly over the fictional world but participating bodily in the causal events of the plot. In one of the first 'Young Men' tales from April I 829, the metaleptic rupture between ontological levels culminates in an extreme antithesis of 'the Christian distance between the individual and his god' - at least, after the death of Christ a point of physical contact: ${ }^{43}$

On the thrones sat the Princes of the Genii. In the midst of the hall hung a lamp like the sun. Around it stood genii, and fairies without, whose robes were of beaten gold sparkling with diamonds. As soon as their chiefs saw us they sprang up from their thrones, and one of them seizing $A[r t h u r]$ W[ellesley] and exclaimed, 'This is the Duke of Wellington!' (EW I4)

This is, of course, a rewriting from a fictional perspective of the real events she had detailed in the 'History' the previous month:

Branwell came to our door with a box of soldiers. Emily and I jumped out of bed and I snatched one up and exclaimed, 'This is the Duke of Wellington! It shall be mine!' ( 5 )

Read together, these two accounts create a parallax of the relation between the bodies of Brontë and the Duke of Wellington - a giant Chief Genius, holding a man; a ten-year-old child, holding a wooden soldier - such that, even as the dizzyingly different senses of scale recognises the distinctness of two perspectives, their fusion through a single proportion also affirms their continuity. ${ }^{44}$ Reading together, keeping in mind both the contingency of the character's encounter with the world and the possibilities of the author's power over fiction, is also the cognitive position upon which the juvenilia recurrently insists. Its fundamental incompatibility with orthodox approaches to the author (living or dead) suggests another way of rendering the 'intelligibility' of authorial decisions and actions, even beyond the 
idiosyncratic productions of children: another counter-theology, with a different mode of interpreting creation, not the death of the godlike author but their transformation into genii.

The metaleptic touch of the author is a gesture which embodies a radically alternative theory of realism and fiction to that of observation, representation, and abstraction. The uncomfortable directness, power, and potential for pleasure contained within the gesture - an author seizing their fiction by force - upends the model Levine constructs of Victorian realists who heroically 'save meaning at the sacrifice of pleasure':

[I]n requiring a continuing alertness to the secret lust of the spirit to impose itself in the world [...] in resisting the romance forms that embody those lusts, [realism] is always on the verge of another realism: the recognition that the reality it most adequately represents is a subtly disguised version of its own desires. ${ }^{45}$

Levine's work in The Realistic Imagination is an attempt to rescue Victorian realism as a project 'to make contact with the world out there, and, even with their knowledge of their own subjectivity, to break from the threatening habits of solipsism, of convention, and of language'. ${ }^{46}$ By saving pleasure (seemingly) at the sacrifice of meaning, and in making the wrong kind of 'contact' between worlds, the Brontë juvenilia passes over the 'verge' into what critics from Gaskell to Leavis, from Eliot to Levine, have represented as a surrender of the serious moral value of literature to either the solipsism of language or the selfishness of desire. Yet if 'the secret lust of the spirit' is always constitutive in the novel, part of its profound ambivalence, the case of the juvenilia offers novel criticism an opportunity to take its fulfilment seriously as a possible function of the form, rather than its collapse. ${ }^{47}$ Play shows us that a world of desire can have its uses, especially in the formal disguise of reality; and that virtual actions can be meaningful, if we take the participatory perspective of those performing them.

The next part of this chapter applies this perspective in a reading of Brontë's first full-length novel, The Professor, proposing how its narrative reaches not for 'the world out there', but for the virtual world of fiction. For Brontë, critics have argued, the transition of writing into a professional practice required affecting a distance or detachment from using writing as a form of vicarious action. The Professor narrates the laborious career of William Crimsworth, a clerk-cum-teacher who masters social and economic obstacles through effort and discipline, and has therefore been read as a rejection of the juvenilia's excesses for a novelistic seriousness about 
depicting the experience of economic precarity or Victorian individualism. But as I will point out, the novel is itself excessive in its depictions of powerlessness and vindication, as the protagonist's improbable habits of self-improvement produce equally improbable results, in ways not so different from the wish-fulfilment of either the juvenilia or of Brontë's second novel, Jane Eyre.

This interpretation represents a significant intervention into the established picture of the generic relationship between Brontë's juvenilia and mature novels, but also more generally, demonstrates the potential interventions of a participatory criticism. Emphasising how The Professor fails as a historical representation, but succeeds as a historical fantasy, reveals the novel's alternative value for providing an experience of imagined power and action, instead of an accurate or inaccurate depiction of material experience. As Dames has put it:

Contextualist work on fiction often functions as our own, lapsed form of Incarnation. The work of imaginative literature is studied for the way it betrays, reflects, expresses, or encodes [...] the History that speaks through it. At its simplest, contextualist work risks effacing the fictionality of fiction - its counterfactuality, its incomplete adherence to the historical real, its artifactuality[.. ${ }^{48}$

Dames's reference to Hegel brings the theology of realism into contact with a question of critical methodology: if the critic can too easily reduce an imaginative experience to a historical one, realist authors may have more difficulty and less incentive in 'effacing' the unique possibilities afforded by fiction. Following Brontë from play to the novel, we will attempt to identify the submerged practice of 'another realism', interested in a different type of real. 


\section{THE PROFESSOR}

I want to redeem a form of metaleptic interpretation, now thoroughly disavowed in Brontë scholarship, which reads Brontë's fiction as a combination of biographical experience and unlived fantasy. 'Charlotte Brontë is Jane Eyre', Mary Augusta Ward wrote in I899, 'You cannot think of her apart from what she has written'. ${ }^{49}$ Anne Thackeray Ritchie recalled casually in I894 of once meeting Brontë 'when my father [William Thackeray] had invited a party to meet Jane Eyre at his house'. ${ }^{\circ}$ Although part of a generally admiring mythification of the author, this critical and popular practice in the nineteenth and early twentieth century of placing Brontë into her novels had embarrassing implications from the beginning. As early as I 856 , while waiting to see the unpublished manuscript of The Professor, Gaskell had 'dreaded lest the Prof: should involve anything with M. Heger', the Belgian schoolmaster and employer with whom Brontë had been infatuated: 'I have not seen the Professor as yet [...] but I am afraid it relates to M. Heger, even more distinctly \& exclusively than Villette does'. ${ }^{\text {I }}$ The potentially awkward comparisons between Brontë's romantic experiences, The Professor, and Villette (the novel of an English teacher's relationship with a foreign professor) were ultimately reinforced by Gaskell's own text - The Life of Charlotte Brontëwhich despite its best intentions, informed a strongly biographical reception of The Professor's posthumous publication. The reviewer for The Examiner surmised that 'Into the character of the Professor himself the writer has transferred much from her own nature'; the North British Review, that 'the Professor is a woman in disguise [...] for she is quite properly stripped of her male costume, and turned into "Lucy Snowe" in Villette'; and the Critic, that 'William Crimsworth is a Jane Eyre in petticoats' ${ }^{52}$ Henry Houston Bonnell's study in 1904 takes this to its logical conclusion: 'Lucy Snowe is Charlotte Brontë, as is Jane Eyre, and as is the Professor'. ${ }^{3}$

Critics from the I960s onwards have rightly repudiated such equations as reductive, patronising, or disparaging of Brontë's artistry, offering instead interpretations of how her texts 'speak to' greater and more abstract realities of gender, politics, or historical conditions (or Barthes's 'hypostases': 'reason, science, the law'). ${ }^{54}$ At the same time, however, vicarious identification and pleasure remain undeniably central both to many readers' experiences of her novels and to her protagonists' own uses of narrative. The denouement of The Professor, for example, is fictionalised by one of its characters before it is realised by the narrative itself. 
The protagonist William Crimsworth, having finally overcome his financial difficulties and able to propose marriage to his former student, enters her room to find her composing poetry. Francis Henri's poem tells an idealised narrative of their relationship, featuring a character named Jane and an unnamed schoolmaster, concluding in their separation by circumstance and with the Master's call for Jane to 'Come home to me again!'s For Crimsworth, what the poem makes clear is 'that "Jane" was now by my side; no child but a girl of nineteen, and she might be mine, so my heart affirmed' (TP 222), spurring him to propose. His interpretation simultaneously opens up and closes the gap between reality and fiction (for us, between The Professor and its mise en abyme): at the sentence level, Crimsworth's confident identification of Frances as Jane ('Charlotte Brontë is Jane Eyre') is in tension with the immediate caveat that Frances is 'no child but a girl of nineteen', and with the quotation marks that bracket out 'Jane' as only conditionally interchangeable with her author. More generally, Crimsworth's realisation that Frances is 'now by my side' and 'might be mine' is paradoxically 'affirmed' by her conflation with a fictional 'Jane' who, by the end of the poem, is in fact physically separated from her lover. Crimsworth's proposal revises in life the ending to a narrative originally based on his life, effecting a divergence between life and fiction by leveraging a recognition of their convergence.

This strategy of 'incomplete adherence' between fiction and reality is also employed by Frances's poem itself, which despite its recognisability as a reflection of her experiences and situation, also makes significant departures from them. ${ }^{56}$ Although the narrative of Jane's relationship with her master and the impossibility of their union neatly summarises the events of The Professor so far (except that Frances is unaware of Crimsworth's good news), in a notable diversion from the real events, the poem also includes explicit declarations of love:

They called in haste; he bade me go,

Then snatched me back again;

He held me fast and murmured low

'Why will they part us, Jane?' (TP 22 I)

Such inclusions diverge significantly from Frances's consistently undemonstrative relationship with the taciturn Crimsworth, who even when arriving to propose, 'had shown no eagerness [...] we met as we had always met, as Master and pupil, nothing more' (216). The stanza's imagining of being 'snatched' and 'held [...] fast' in fact pre-empts and inspires an uncharacteristic outburst which elicits 'Amazement' from Frances: 'one moment 
I was sitting [...] the next, I held Frances on my knees, placed there with sharpness and decision, and retained with exceeding tenacity' (222). The poem does not only encode Frances's experience of the relationship but also her wish, and in doing so, happens to become the agent of its fulfilment. Similarly, while Frances's tutelage under Crimsworth has been cut short in the novel by her dismissal from the school, the poem grants Jane her academic victory and emotional reward.

At last our school ranks took their ground;

The hard-fought field, I won;

The prize, a laurel-wreath, was bound

My throbbing forehead on. (220)

Both of these embellishments on the actual narrative events set the poem at a middle distance from Frances's life, one that even Crimsworth describes as 'not exactly the writer's own experience - but a composition by portions of that experience suggested; thus while egotism was avoided, the fancy was exercised, and the heart satisfied'. (2 I7) The poem is located as loosely suspended on an incomplete relation between creation and description, of fiction 'suggested' by 'portions of [...] experience', and further triangulated to a space between 'egotism', 'fancy', and personal satisfaction.

It is exactly this space which criticism cannot comfortably examine or occupy. Recognitions of Brontë's own wishful or intimate involvement in her writing have historically resulted in judgements like Q. D. Leavis's disparagement of popular fiction, that 'the author is himself - more usually herself - identified with the leading character, and the reader invited to share the debauch [...] as a compensation for personal disabilities and disappointments'. ${ }^{57}$ Jane Eyre in particular became a target for Leavis's powerfully embodied disgust towards self-indulgent immersion within fiction:

Jane Eyre is [...] a fable of wish-fulfilment arising out of experience, in which figure such common indices as the child's burning sense of injustice, self-idealisation [...] blinding and maiming of the beloved to enhance the value of the subject's devotion, self-abasement to the verge of death followed by dramatic salvation, recognition by enviable relatives, etc [...] the appeal of the commoner day-dreams is inexhaustible - they represent both for author and reader a favourite form of self-indulgence. ${ }^{58}$

On the other hand, the reclamation of Brontë and her work from these charges - through emphasising her engagement with gender oppression, 
working-class politics, literary networks, and scientific discourse - has therefore tended to elide the features which Leavis is essentially accurate in pointing out. As Heather Glen argues in her 1989 introduction to The Professor, Brontë's fiction is 'more searching, more flexible, more disinterestedly intelligent' than nineteenth- and early twentieth-century accounts credit, and deserves 'a full alertness to the sophisticated literary intelligence that is manifest in its pages [...] a different Charlotte Brontë from the unreflective novelist of private love and longing that she is all too often taken to be'. ${ }^{9}$ Yet in her 2004 study of Jane Eyre, Glen is also openly ambivalent about the catalogue of narrative results, an echo of Leavis's 'common indices', she compiles from the divine justice doled out to the novel's characters:

Investigation into the affairs of Lowood produces 'a result mortifying to $\mathrm{Mr}$ Brocklehurst'; John Reed's is a 'shocking' death, and his mother's a desolate one. The Reed sisters are disposed of [...] Bertha Rochester dies [...] Blanche Ingram, is categorically dismissed by the man she has sought to entrap. Rochester is blinded, injured, and domesticated [...] By the end, [Jane] is paramount: those who have sought to wrong her are punished, her decisions are vindicated and her desires fulfilled. ${ }^{60}$

Even as modern criticism has increasingly demonstrated more context, sophistication, and criticality in Jane Eyre than simple vicarious 'wishfulfilment', it seems undeniable that the novel is also one in which 'Jane's uncontested narrating voice, rewarding her friends and punishing her enemies, oddly recalls the great Genii of Glass Town' in its omnipotent removal of obstacles and realisation of desires. ${ }^{6 \mathrm{I}}$

The following reading of The Professor moves backwards in critical history, stepping momentarily out of the new consensus on Brontë's disinterested reflectiveness to reappraise her use of fiction 'as a compensation for personal disabilities and disappointments'. ${ }^{62}$ As critics have shifted focus away from the apparent biographical realities in Brontë's novels towards more abstract and structural realities, this has also been a movement towards more impassive, Flaubertian relations between reality and the novel. ${ }^{63}$ As we have seen, however, the conceit of the Chief Genii suggests Brontë's development of 'another realism', the writing of a plausible yet explicitly conjured reality which is no less the product of a 'sophisticated literary intelligence' than more orthodox forms of realist representation. ${ }^{64}$ Their resurfacing in Jane Eyre's narration, and in the self-realising power of Frances's poem, point to something left behind by criticism: a partial yet desirable correspondence between life and fiction, 
'not exactly the writer's own experience' (TP 217 , emphasis added), which balances the aim of vicarious satisfaction with an avoidance of direct 'egotism'. Practices of wish-fulfilment in Brontë's novels require a reassessment that does not necessarily entail a return to reductivism or disparagement. Rather, Frances and Crimsworth demonstrate the potential for producing real gratification from the very possibility of the novel's inexactness to history, and in doing so, suggest alternative means for using and valuing realism's distinctive verisimilitude.

\section{Work Ethic and Work Aesthetic}

The issue of what kind, degree, or specificity of reality enters the novel seems to have been foundational to Brontë's own attachment to her first completed, post-juvenilia work. Two months after the publication of Jane Eyre in I 847, the novel written after The Professor had been repeatedly rejected by publishers, she offered to rework her first manuscript and argued that 'the middle and latter portion of the work, all that relates to Brussels, the Belgian school etc [...] contains more pith, more substance, more reality, in my judgement, than much of "Jane Eyre". ${ }^{65}$ Shortly after the publication of Shirley in I 849, Brontë offered it again to an unreceptive Elder and Smith, drafting a new preface which once more defended the novel on the basis of the 'real':

I had not indeed published anything before I commenced 'The Professor' but in many a crude effort destroyed almost as soon as composed I had got over any such taste as I might once have had for the ornamented and redundant in composition - and had come to prefer what was plain and homely [...] I said to myself that my hero should work his way through life as I had seen real living men work theirs - that he should never get a shilling he had not earned - that no sudden turns should lift him in a moment to wealth and high station - that whatever small competency he might gain should be won by the sweat of his brow - that before he could find so much as an arbour to sit down in - he should master at least half the ascent of the hill of Difficulty - that he should not even marry a beautiful nor a rich wife, nor a lady of rank. (TP 3-4)

Such a preface is typical of what Levine identifies as 'realism's most overt anti-literary manifestos', the pre-emptive defences which arise out of an inherent 'self-consciousness in realistic fiction [...] awareness both of other literature and of the strategies necessary to circumvent it, and - at last - its awareness of its own unreality'. ${ }^{66}$ Here, The Professor takes on a 'plain and homely' opposition to both the juvenilia (misrepresented as 'destroyed') 
and to Jane Eyre ${ }^{67}$ As Glen points out, almost everything explicitly denied to Crimsworth - 'unearned wealth, a transformative marriage, excessive happiness' - recall those qualities which most expose Jane Eyre as transparently desire-driven. ${ }^{68}$ Less explicitly, the visualisation of the plot through Bunyan's allegory - 'the hill of Difficulty' along which 'no sudden turns should lift him' (3-4) - also reads in its verticality like a harsh correction to the juvenilia's magical conception of plot: the 'great obstacle' of the park gate, over which the authors personally 'took Raton up and threw him' ( $E W$ 26). What 'more pith, more substance, more reality' seems to indicate in Brontë's preface is less wish-fulfilment - 'never [...] a shilling he had not earned', 'no sudden turns', 'not even [...] a beautiful nor a rich wife' (TP $3-4$, emphasis added) - and in its place, moderate rewards earned only through practical life.

For much of The Professor, this premise of a realistic narrative manifests as serial episodes of perseverance against intractable forces, or in other words, as the bildungsroman's necessary confrontations with a contingent world. The introduction, which frames the first chapter as Crimsworth's letter to an old school-friend, characterises the implied reader as 'a sarcastic, observant, shrewd, cold-blooded creature' $(5)$ whose very reading must be forced from him: as Crimsworth remembers from Eton, 'when I recurred to some sentiment of affection [...] your sardonic coldness did not move me - I felt myself superior to that check then as I do now' (6, original emphasis). The end of the chapter acknowledges that the letter goes unanswered, a fatal 'check' that Crimsworth overcomes by readdressing the novel to the public. The narrative's (and the novel's) own struggle to exist sets the stage for the story of Crimsworth's career, which analogously struggles to be realised within an unreceptive and hostile market. Initially employed as his brother Edward's clerk, Crimsworth is warned that 'I shall excuse you nothing on the plea of being my brother; if I find you stupid, negligent, dissipated, idle or possessed of any faults [... I I shall dismiss you as I would any other clerk. $£ 90$ a year are good wages and I expect to have the full value of money out of you' (I9). Their mutual brotherly antipathy, which dominates this first section of the novel, is in some sense a perfectly matched relationship: Edward's intention to extract 'full value' from his brother's labour, and his aggressive abstraction of their familial relation into an economic exchange, mirrors Crimsworth's attitude on eventually receiving his wages 'possessed heart and soul with the pleasant feeling that the master, who had paid me, grudged every penny of that hard-earned pittance' (3I). Both ostensibly private relationships - school-friends as cold readers who must be brought to 
attention; brothers as economic agents from whom profit must be maximised - are alienated into the hostilities of public readers and the market. Real life, for The Professor, is indeed a 'hill of Difficulty' (3-4) in which conflict is environmental and gravitational, an undifferentiated field of opposing forces resisting the individual climber.

Moreover, the reciprocity between the brothers points out that, if help is nowhere to be expected, it is also deeply not to be desired. Despite the cynicism with which he expresses it, Crimsworth is serious in his retort to Edward that 'not to expect favour from you and not to depend on you for any help but what I earn - that suits me exactly' (19). This aversion to personal favour recurs pathologically throughout the novel. In his severing of ties to his aristocratic uncles, Crimsworth describes as 'my reward' to see 'one of them [throw] down on the table before me a $\mathfrak{L}_{5}$ note which I was able to leave there - saying that my travelling expenses were already provided for' (22). Later, after the plot relocates to Brussels, he thanks Victor Vandenhuten, a kind and willing patron, for writing an honest reference and for not offering financial assistance: 'You have made me quite happy and in a way that suits me; I do not feel an obligation irksome, conferred by your kind hand; I do not feel disposed to shun you because you have done me a favour' (2 I2). This model of patronage is contrasted, in the same chapter, with the unexpected gift of a longed-for portrait of Crimsworth's mother, saved from auction by his rival Hunsden Yorke Hunsden, whose accompanying note teases that 'There is a sort of stupid pleasure in giving a child sweets [...] repaid by seeing the child besmear his face with sugar [...] In giving William Crimsworth his Mother's picture, I give him sweets' (209-10). Crimsworth's initially sentimental response instantly sours:

I muffled the picture in its green baize covering, restored it to the case and having transported the whole concern to my bedroom, put it out of sight under my bed. My pleasure was now poisoned by pungent pain [...] I should have said to him 'I owe you nothing, Hunsden - not a fraction of a farthing - you have paid yourself in taunts'. (210)

As Glen puts it, 'Instead of Dickens's great metaphors of circulation and stoppage, or George Eliot's of the social web, there is a singular story of individual self-help' ${ }^{69}$ Given Crimsworth's rejection and disgust of outside interference in his affairs, this is indeed self-help in a literal sense, or self-help by process of elimination. The preface's implicit contribution to (and perhaps, endorsement of) this attitude is the apparent withdrawal, too, of the author's help, as if the appearance of a sudden heiress in the plot 
would also represent an unwanted and inappropriate gift. Realism, in the sense of the absence of supernatural and metaleptic interventions, here meets realism as characterised by a particular picture of the social - the effect of which is to leave Crimsworth solely responsible for bringing about both his career and his narrative through 'the sweat of his brow' (3).

Modern critics have read this begrudging narrative one of two ways: as either an endorsement or a critique of 'self-help' as a historical ideology, an aspect of what has long been touted as the Victorian work ethic. Although the term itself would not be popularised until Samuel Smiles's publication of Self-Help in I 859, Glen notes how 'the lectures that formed the basis of Smiles's best-seller [...] were first delivered to a young men's mutual improvement society in Leeds in I 845 - the year in which, very probably, only a few miles away, The Professor was conceived'. ${ }^{70}$ Shuttleworth similarly argues that it is relatively easy to trace many tantalizing examples of [Brontë's] connections with local self-help culture'. ${ }^{71}$ Whatever the case may be of Brontë's possible encounter with Smiles, there is clearly a shared cultural wellspring between The Professor's 'hill of Difficulty' and SelfHelp's liberal-individualist view of life: 'The battle of life is, in most cases', Smiles writes, 'fought up-hill; and to win it without a struggle were perhaps to win it without honour. [...] The road to success may be steep to climb, and it puts to the proof the energies of him who would reach the summit'. ${ }^{72}$ This culture of self-realisation through labour, culminating in Smiles's philosophy but circulated throughout Victorian social theory, has been widely identified by criticism as the appropriate context for understanding the premises of The Professor.

Yet critical interpretations have been divided on the novel's ideological stance towards this context - namely, its critique of or collusion in a selfhelp view of the world - which I outline here in order to offer a third solution. For Shuttleworth and Glen, on the side of critique, Brontë's representation of self-help culture exposes its inherently oppressive effects. In this interpretation, Crimsworth's commitment to a philosophy of selfimprovement is a critical and ironic depiction, rather than an endorsement; as these critics point out, the efforts with which he overcomes difficulty and asserts his independence are explicitly and brutally selfdirected:

I served Edward as his second clerk faithfully, punctually, diligently. What was given me to do, I had the power and the determination to do well. [Edward] Crimsworth watched sharply for defects but found none; he set Timothy Steighton, his favourite and head-man, to watch also, Tim was baffled; I was as exact as himself, and quicker: Mr. Crimsworth 
made enquiries as to how I lived, whether I got into debt - no - my accounts were always straight [...] [from] the accumulated savings of my Eton pocket-money; for as it had ever been abhorrent to my nature to ask pecuniary assistance, I had early acquired habits of self-denying economy [.] ( $T P$ 22)

Such a strategy of gaining victory over surveillance (Edward's 'watch' and 'enquiries') by having nothing to hide, economising oneself into miserliness, and providing more than perfect work, stands out as an exemplary form of Foucaultian self-discipline or what Sedgwick describes as paranoid logic: 'Anything you can do (to me) I can do first - to myself. ${ }^{73}$ Shuttleworth notes along these lines that he defeats his brother, he suggests, by his ability to police internally his own mental traits [...] Crimsworth's language underscores the interdependence of theories of interiorized selfhood and external structures of surveillance. His sense of the primacy of a pre-existent realm of selfhood is illusory'. ${ }^{74}$ More to the point, she argues that this 'textbook account of the social and psychological value of self-control [...] functions rather to highlight the structural violence implicit in these ideological formations. ${ }^{75}$ Glen concurs that Crimsworth's character - explicitly like the 'dependent and determined' perspective she ascribes to the juvenilia - is 'one of abnegation and refusal [...] neither expressively self-actualizing nor freely selfdetermining', and therefore that 'the novel seems to be pointing to a fundamental contradiction in that self-sufficient individualism which Crimsworth seeks to affirm [...] his vaunted independent "exertion" is in fact wage slavery'. ${ }^{76}$ For these essentially congruent readings, the novel exacerbates and makes visible the cracks in the morality it reproduces through narrative.

For other critics, taking the opposite approach, this irony is so subtle as to be absent, and the novel instead genuinely perpetuates a middle-class myth of egalitarian achievement through difficulty. Terry Eagleton's classic Myths of Power points out 'a dissonance between what the novel shows and what the Preface claims for it', unravelling the novel's claims to be a story of individualist effort, because Crimsworth is 'after all an aristocrat by birth, furnished with privileged accomplishments which he can put to profitable use'. ${ }^{77}$ Catherine Malone has similarly registered the jingle of 'Eton pocket-money' (TP 22) jarring Crimsworth's protestations of austerity, arguing that 'Crimsworth's life is not one of true sweat or labour because throughout the novel he is able to rely on the privileges of his sex and class'. ${ }^{78}$ This argument reaches its most explicit manifestation in 
Neville Newman's (partly satirical) representation of Crimsworth as a kind of modern Oxbridge graduate:

William Crimsworth is an Eton-educated scholar steeped in the classics who chooses to make his living by teaching in a continental private school for girls after a brief and unsuccessful attempt at commerce in the counting house at his brother's mill [...] The sweat which he is expected to expend is, in his case, metaphorical at best. Less generously, the expression illicitly seeks to equate Crimsworth with the workers (for whom the sweat of their brows can only ever be literal) while simultaneously erasing a recognition of the reality of their efforts. ${ }^{79}$

Here, the illusion of 'the hill of Difficulty' is not internalised but projected; what disappears from the novel under analysis is not the self but work, exemplified by the evaporation of Crimsworth's 'sweat' as being untrue or metaphorical. What reappears are the millworkers, with 'literal' sweat and a 'reality' of labour, whose indistinct presences are noted but never in focus during the protagonist's employment at the mill. Contrasted to Shirley, where the deprivation of millworkers' families, the violence of machinebreaking, and the financial risk of employers are all explicitly (if no less contentiously) represented, Crimsworth's miserliness and work ethic are in fact curiously disconnected from both his own material conditions and the economics of his workplace. His alleged 'wage slavery' appears purely for its own sake - or in Newman's reading, for the sake of appearance.

Both interpretive camps, wildly divergent in their conclusions, nonetheless proceed from a shared political conviction: self-help does not work. Historically and philosophically, the patient submission of individuals to exploitation does not create the self-actualisation and social security that Smiles, Crimsworth, and Carlyle claims it does. Whatever the novel's real position, its internal narrative of individualist achievement cannot realistically co-exist with its claim to represent the external reality of labour either Crimsworth's triumphant selfhood must be revealed as 'illusory', or his labour must be exposed as 'metaphorical'. Jennifer Ruth's recent and incisive reading inverts this problem into a dilemma about the visibility of intellectual labour, noting that while Crimsworth's work is admittedly derived from an innate capital of education and skills he himself calls 'mental wealth', Brontë also 'pointedly refuses the assumption that immaterial labor does not count as real work, that metaphorical sweat cannot convey true effort'. ${ }^{80}$

Such contradictions in the nature of work are not easily resolvable in life, but I want to propose, as an intervention, that they are resolvable in fiction - if only with a form of interpretation which renders fiction 
unusable to this kind of political critique. The Professor can be read 'straight' - as the 'apparently simple story of obstacles surmounted, effort rewarded, and victory won' promised by the preface - if, instead of the self or the struggle, the disappearing trick is performed on the novel's referential relation to the actual. ${ }^{8 \text { I }}$ Ruth's reading of mental work, which poses as one of its central questions how to make 'immaterial labor' and 'metaphorical sweat' gain substantiality and literality, suggestively verges onto (without addressing) another, more metafictional question: what is the literality or substantiality of representational sweat, narrative labour, and fictional work? Rather than a critique, a misrepresentation, or an exploration of 'immaterial' work in the sense of intellectual labour, what would it mean for Crimsworth's work to be immaterial in the sense of imagined? Another way of understanding the novel's premises, as well as its political or ethical functions relative to historical experience, lies in fiction's explicit difference from reality and its capacity for wish-fulfilment.

\section{The Pleasure of Fictional Work}

To play out the Victorian work ethic in fiction is of course much more satisfying than embodying it in real life; indeed, what Brontë and Crimsworth perhaps identify here is the proper plane on which such values are in fact operable. If Crimsworth's desire to 'have set up the image of Duty, the fetish of Perseverance in my small bed-room' as guards against 'my Cherished-in-secret, Imagination' (TP 30) is troubling as the representation of a historical worker, this belaboured characterisation of realistic life also belies the equivalence between its apparent opposition: as 'image' and 'fetish', the values of self-help are themselves mediated through the 'Imagination' for the reader and the protagonist. Moreover, Crimsworth's commitment to self-help also manifests as fetishistic in the libidinal sense; when he realises that his affections have been toyed with by Zoraide Reuter, a Belgian schoolmistress, he regains his self-esteem by choosing 'to face her with firmness' (I I 3 ):

[S]he had held her hand to me - that I did not choose to see - she had greeted me with a charming smile - it fell on my heart like light on stone [...] meeting her gaze full; arresting, fixing her glance, I shot into her eyes from my own a look where there was no respect, no love, no tenderness, no gallantry, where the strictest analysis could detect nothing but scorn, hardihood, irony; I made her bear it and feel it; her steady countenance did not change but her colour rose and she approached me as if fascinated. (I $\left.13-\mathrm{I}_{4}\right)$ 
This erotic encounter is modelled on the same 'abnegation and refusal' as his economic, social, and narrative struggles, and his tactics here echo his paranoid encounters with his family's condescension and surveillance - to evade detection of injury, he renders the self barren; to reject bad offers, he learns to do without. ${ }^{82}$ Yet this episode of sexual refusal is also remarkably similar in its method and effects to its opposite, sexual advance: 'I shot into her eyes from my own [...] I made her bear it and feel it [...] her colour rose' (I I 3-I 4). Later, teaching a class of Reuter's schoolgirls who 'talked to me occasionally with their eyes, by means of which [...] [they] say very audacious and coquettish things' (I I 8), he moralises that their immodesty meant 'I found pleasure in answering the glance of vanity with the gaze of stoicism' (I I9, emphasis added). These erotic exchanges model explicitly the way in which all of Crimsworth's encounters with difficulty implicitly generate what he calls 'the pleasant feeling' (3I) of grudging his brother (and himself, and everyone else) - of triumphant, almost masochistic perseverance. This equivalence between erotic and professional struggle reveals their shared economy with the pleasure of fictional difficulties, overcome with imagined effort and ultimately yielding narrative pleasures.

By inverting difficulty into invigoration, self-denial into self-pleasure, the erotics of The Professor embody the perversities of economic individualism not to critique or to endorse, but to take vicarious part in the imaginary pay-offs the philosophy offers (but cannot really deliver). In this light, Asa Briggs's observation that sales of Self-Help 'far exceeded those of the great nineteenth-century novels' suggests new questions about the comparative functions of these two genres, ${ }^{83}$ one which reverses fiction's subordination to a 'first-person version of the narrative of self-help' or a 'textbook account of [...] social and psychological value'. ${ }^{84}$ An ideology which spells powerlessness for its historical subjects undergoes an inevitable transformation in its replication by fiction, because there it must encounter the absolute power inherent to the position of the author. To discover the preface's 'hill of Difficulty' (TP 3-4) echoed in the narrative itself is to recognise this metaleptic transformation: on the voyage from England to Belgium, Crimsworth echoes his creator by considering himself as like a morning traveller who doubts not that from the hill he is ascending he shall behold a glorious sunrise; what if the track be strait, steep and stony? he sees it not - his eyes are fixed on that summit' (56). Just as he most vividly realises the 'pleasure' of flirtation by pointedly ignoring it, his metaphor luxuriates in describing those obstacles he 'did not choose to see' (I I3) much more explicitly than the vanishing point to which his attention is supposedly directed: 
'there were pebbles, inequalities, briars on my path, but my eyes were fixed on the crimson peak above, my imagination was with the refulgent firmament beyond, and I thought nothing of the stones turning under my feet or of the thorns scratching my face and hands' (56). Rather than ironic distance, on Brontë and Crimsworth's common 'hill of Difficulty' we might detect the shared pleasure of the author and the narrator at work (or rather, at play) in this hyperbolic combination of self-effacement and self-aggrandisement.

Rather than the oppression of real labour, The Professor depicts a fantastic 'image' of work and a pleasurable 'fetish' of difficulty - a game of pretend career-building. By the end of the novel, its at-first overwhelming sobriety has become a pornographic realism, in which the conventions that supposedly mark out reality - hardship, perseverance, gradualism gratifyingly inflate and exaggerate into implausibility, just as the logic of slow ascension comes to vastly overgrow its original expectations of a 'small competency'. ${ }^{85}$ Eventually setting up their own school, the economic discipline and diligence of Crimsworth and Frances reach superhuman levels, and produce no less amazing results:

Ten years rush now upon me [...] years in which me and my wife, having launched ourselves in the full career of Progress [...] scarcely knew repose, were strangers to amusement, never thought of indulgence [...] harmony of thought and deed smoothed many difficulties, and finally, success bestowed every now and then encouraging reward on diligence. Our school became one of the most popular in Brussels, and as by degrees we raised our terms and elevated our system of education, our choice of pupils grew more select, and at length included the children of the best families in Belgium. (TP 249)

As Brown has rightly noted, if 'for Brontë, "the real" describes a vision of social (rather than divine) justice, in which labor earns its just reward [...] Such a plot can be called 'realistic' only against the marvels of Angria'. ${ }^{86}$ Indeed, it is the tension between the instantaneous magic of writing and the protracted reality of effort, so frequently exploited and explored in the juvenilia, which such a passage recalls in its 'rush' over ten years of apparently ceaseless labour in one paragraph. Indistinct summaries like 'harmony of thought and deed smoothed many difficulties', as well as the transitional phrases 'by degrees', 'grew more', and 'at length', linguistically compact the gradualism of their labour, easily eliding the supposedly arduous effort required to make the Crimsworths' school 'one of the most popular in Belgium'. What Barthes points out in history as 'the conflict of two time spans: the time of the speech-act and the time of the material 
stated [...] the acceleration phenomena of history' can be felt distinctly in the ending of The Professor against the pace of the narration that came before it, but this relative change in speed only reveals how narrated labour has never mapped (and never could) moment-to-moment onto the experience of labour itself. ${ }^{87}$

By the end of the novel, Crimsworth and Francis's labour and capital have transfigured completely and self-consciously into effects of language. The way in which the narrative has noticeably grown and accelerated beyond its initial brief is acknowledged when the Crimsworths retire on the proceeds of capital investment:

Behold us now at the close of the ten years and we have realized an independency. The rapidity with which we attained this end had its origin in three reasons. Firstly; we worked so hard for it. Secondly; we had no incumbrances to delay success. Thirdly; as soon as we had capital to invest, two well-skilled counsellors [...] gave us each a word of advice as to the sort of investment to be chosen. (TP 257)

There is a note of petulant defensiveness to Crimsworth's explanation about the 'rapidity' and scale of their success - 'we worked so hard for $i t$ ' - which belies the fantastical destination at which the narrative has now arrived. That this hard work is now all the more swift, noiseless, and invisible in the narrative can be attributed to the removal of the incumbrances to delay' that allow fictional work to be described and felt, and finally, to the disappearance of 'the sweat of his brow' (3) altogether (metaphorical or fictional) thanks to the profits of wise investment. As Ruth's analysis also notes of this passage:

Representing investment in the market as if Crimsworth were still somehow talking about professional labor does not allow Brontë to get through the passage smoothly [...] Still she chooses this recipe for independence, as if at the last moment she wished to write away the dilemma that disfigures her text, as if representing labor combining with capital as unremarkable would make us less likely to remark on the uneasy combination of mental labor and mental capital that paradoxically, however necessarily, constitutes her own professional. ${ }^{88}$

Yet while the Crimsworths' fortunes are indeed represented as tied to the mental capital of their 'well-skilled counsellors', the exercise of these skills are also hyperbolically contracted into 'each $a$ word of advice' (TP 257, emphasis added), the figurative singularity of which more recalls the Genii incantation, the fairy-tale benefactor, and what the author 'wished', than any application of professional expertise. Describing the novel's ending as 
an elision, contraction, or writing away of labour is therefore to grasp the wrong end of Brontë's wish: what is for Ruth a problem of reification, the compression of the time and effort of labour into the static and inanimate presence of objects or capital, operates in reverse for a metaleptic action, where the fictional efficiency of language can be exploited and expanded into endless amounts of fictional labour and wealth. Such a reversal epitomises the fictionalisation or play of self-help effected by The Professor - of difficulty made, not easy, but fun; the experience of powerlessness transformed, not into critique, but vicarious power.

The Professor is then not the novel of sober realism, the counter to Jane Eyre, that it claims (and is often taken) to be - but this is not an argument for its disparagement. What this reading of vicarious power-play and fictional self-aggrandisement seeks to re-evaluate is not the balance of Brontë's reputation between the 'disinterestedly intelligent' novelist and 'the unreflective novelist of private love and longing', but the validity of this critical dichotomy between which she has historically oscillated. Disinterest is not the precondition of literary intelligence, nor is private desire necessarily unreflective; rather, like Frances's redressing of 'portions of [her] experience' (TP 2 I7) in poetry, The Professor's transformation of the West Riding's growing self-help culture into a tool of fictional self-pleasure exemplifies the inventive, as opposed to reflective, engagements with reality that arise from personal need. In producing a fantasy of her circumstances, Frances is clearly neither misrepresenting nor unaware of her problems, but keenly conscious of (and imaginatively fulfilling) the desires which life has frustrated or made impossible. Similarly, to write an implausibly pleasurable narrative of the social rather than a 'textbook account' is not to be ignorant of reality's dissatisfactions, nor even only to be aware of them, but to actively render them satisfying, to play them, to create narrative gratification where no material gratification exists. 'The many ways selves and communities succeed in extracting sustenance from objects of a culture [...] whose avowed desire has often been not to sustain them', as Sedgwick has written, '[are] No less acute than a paranoid position, no less realistic, no less attached to a project of survival, and neither less nor more delusional or fantasmatic'. ${ }^{99}$ The Professor's implausible story of successful self-help is, in this sense of a strategic engagement with and within reality, a deeply realistic fiction.

This book argues for the real uses of artificial realities, functions of the novel which become operable only if we cease to evaluate its reflectiveness and begin to appreciate the distinctive advantages of fiction. As we have 
seen, the omnipotence of the author to dictate fictional consequences has long been dismissed or elided as an embarrassing corollary of the novel's made-up-ness, its potential exchange of moral, political, or social seriousness for indulgent or arbitrary fantasy. Yet there are ways of responding to historical or existential conditions, other than their faithful representation, which involve the imaginary as part of life and which recognise the novel as a useful object precisely for its less constrained version of the world. In the next chapter, I examine another example of fiction's utility in the novels of Anthony Trollope. For Trollope, too, it is an author's explicit prerogative to invent the narrative, an exercise which he repeatedly depicts in $A n$ Autobiography as improvisational - in other words, making it up as he goes along. Like the godlike author, the improviser can be arbitrary, but arbitrariness often functions as a saving grace for Trollope's characters, revealing their lives to be less rigidly determined than they realised. In their ongoing incompleteness, his narratives acknowledge and depend on the novel's concrete yet flexible reality, a perspective which they cultivate as a possible ethical attitude to life. 